\title{
A History of Commercial Plant Growth Regulators in Apple Production
}

\author{
P.D. Petracek and F.P. Silverman \\ Valent BioSciences Corporation, 6131 Oakwood Road, Long Grove, IL 60047 \\ D.W. Greene \\ Department of Plant and Soil Science, University of Massachusetts, Amherst, MA 01003
}

\begin{abstract}
The term plant growth regulator (PGR) refers to natural and synthetic compounds applied to plants or plant organs to regulate growth or development. PGRs play an important role in commercial horticulture, particular in fruit production. This overview of the history of commercial PGRs consists of 1) a brief history of the discovery of five primary plant hormones or hormone groups (auxins, gibberellins, cytokinins, ethylene, and abscisic acid), 2) background on the commercial development of gibberellic acid (GA $)$, 3) discussion of the development of PGRs for commercial fruit production during the later part of the 20th century, and 4) speculation on future commercial PGR opportunities.
\end{abstract}

\section{DISCOVERY OF PLANT HORMONES}

The discovery and understanding of plant hormones has been key to PGR development. Narratives of these discoveries have been presented elsewhere (Bukovac, 1987; Davies, 1995; Jacobs, 1979; Salisbury and Ross, 1992; Wilkins, 1984). Following is a brief history of the five primary hormones or hormone groups.

Auxins. Auxins were the first group of hormones to be discovered. Some of the earliest work with plant growth regulators is traced back to Charles Darwin and his studies on phototropism of oat (Avena) coleoptile. The phototropic experiments conducted around $1880 \mathrm{dem}-$ onstrated that the coleoptile was responsible for sensing light, and that the light response was transmitted basipetally from the illuminated coleoptile tip (Jacobs, 1979). In a series of papers from 1910-1913, Boysen-Jensen showed that the tip of the coleoptile was the source of the phototropic effect and that a diffusible substance produced in the tip could pass through a layer of agar to confer phototropism. Went used agar blocks in the development of the first bioassay, the Avena coleoptile bending test, and the eventual identification of indole acetic acid (IAA) as the endogenous auxin in plants (Bandurski and Nonhebel, 1984; Jacobs, 1979).

GibBerellins. The discovery of gibberellic acid $\left(\mathrm{GA}_{3}\right)$ by Japanese workers illustrates the contribution of plant pathologists to PGR research. The fungus Gibberella fujikuroi causes Bakanae disease or foolish rice disease resulting in abnormally tall seedlings. During the 1930s, Japanese scientists isolated impure gibberellins from fungal culture filtrates (Phinney, 1983). However, the lack of communication among scientists during wartime caused their work to be largely overlooked. After the war, Imperial Chemicals Industries (ICI), now part of Syngenta, obtained cultures of the fungus. In 1955, ICI reported the isolation and characterization of $\mathrm{GA}_{3}$ (Brian and Hemming, 1955). While there are currently over 130 gibberellins known to date, only $\mathrm{GA}_{3}, \mathrm{GA}_{4}$ and $\mathrm{GA}_{7}$ are used commercially.

CYTOKInINS. The initial attempt to identify a cytokinin was performed in Went's lab by Bonner (1940). He discovered that a diffusate from the soak water of pea seeds increased the growth of excised leaf discs. In addition, Bonner determined that yeast extract had considerable activity in the leaf disc bioassay. Fractionation of the yeast extract demonstrated that adenine, hypoxanthine and xanthine increased growth of excised leaf disks. The isolation of hypoxanthine supported the argument for a purine-based hormone (cytokinin). However, the adenine activity in the leaf disc bioassay was difficult to reproduce (Jacobs, 1979). It remained for the lab of Skoog at the University of Wisconsin to develop callus culture techniques and to understand the need for an auxin/cytokinin balance in the development of plant organs. In Skoog's lab, Miller used fractionated yeast extract in the cell culture system. In addition to screening commercially available purines, including adenine, Miller tested degraded herring sperm DNA. The resulting cytokinesis was found to be due to kinetin produced during
DNA breakdown (Miller et al., 1955). Kinetin was significantly more active than adenine in the tobacco tissue culture bioassay. The use of the plant cell culture bioassay was a key to the eventual isolation of zeatin from corn by Letham (1963).

ETHYLENE. The growth regulating properties of ethylene were first recognized by the Russian scientist Nejebulov in 1901 (Beyer et al., 1984). His experiments showed that illuminating gas could cause leaf abscission and epinasty. The fruit physiologist Crocker developed the Alaskan pea bioassay that used the triple response of shortening and thickening of the hypocotyl, agravitropic growth, and maintained hypocotyl hook (Reid and Howell, 1995) to assess ethylene levels. He was the first to suggest that ethylene was an endogenous plant hormone. However, few scientist at the time agreed with Crocker since it was difficult to visualize that a gas could act as an endogenous regulating substance. It was not until the 1960 s when gas chromatography was used to quantify endogenous ethylene that the significance of ethylene was recognized and acknowledged as an endogenous hormone.

ABsCISIC ACID. While researchers had long speculated that a hormone which affected abscission, dormancy, and stress reduction existed, it was not until the 1950s that work on the isolation and identification of this compound began. In 1953 Bennet-Clark and Kefford discovered an acid fraction of plant extracts that was a potent growth inhibitor. In 1955 Osborne reported on the diffusion of a senescence factor from older leaves that could speed the abscission of bean petioles. By 1963, Addicott's group studying cotton fruit abscission in California had identified and characterized abscisin II. At the same time, Wareing's group in Wales identified the dormin as a compound that promoted dormancy in woody plants. In 1968, these groups formally redesignated abscisin II and dormin as abscisic acid (Milborrow, 1984).

\section{COMMERCIAL PRODUCTION OF GA}

$\mathrm{GA}_{3}$ was among the first compounds to be widely used as a PGR. Consequently, commercial production of cost-effective $\mathrm{GA}_{3}$ has become is an important part of the history of PGRs.

Impure gibberellins were isolated from fungal culture filtrates in Japan during the 1930s, but the first isolations of pure gibberellins were made at ICI in the United Kingdom during the mid-1950s. However, during the late 1950 s, ICI decided not to enter the U.S. marketplace, but to market $\mathrm{GA}_{3}$ products in the rest of the world. As a result ICI licensed $\mathrm{GA}_{3}$ to a consortium, the Gibberellic Acid Registration Task Force. This task force, formed by Merck, Eli Lilly, Abbott Laboratories, Pfizer, and American Cyanamid, was to develop $\mathrm{GA}_{3}$ products for the U.S. marketplace (Robert Cibulsky, personal communication). Eli Lily was the first company to register a $\mathrm{GA}_{3}$ product for use on seedless grapes in 1960. Abbott Laboratories and Merck registered $\mathrm{GA}_{3}$ products shortly thereafter.

Many current uses for GA 3 were not known in 1960. Eli Lilly's first label included uses for their product on grapes only. The preharvest use of $\mathrm{GA}_{3}$ on lemons was added to the Abbott label in 1963. The use of $\mathrm{GA}_{3}$ on sour cherries (Prunus cerasus) was added to the product label by 1965 .

$\mathrm{GA}_{3}$ use was initially restricted by product cost. ICI had found that neither chemical synthesis nor extraction of $\mathrm{GA}_{3}$ from plants was economical. In the late 1960s Abbott Laboratories commitment to improving the fermentation of $\mathrm{GA}_{3}$ through a strain improvement program led to significant cost reductions over a 10 -year period (Robert Cibulsky, personal communication). The resulting lower product cost was more acceptable to commercial growers and the commercial use of $\mathrm{GA}_{3}$ increased. 


\section{DEVELOPMENT OF PGRS FOR COMMERCIAL APPLE PRODUCTION}

Control of growth and development of fruit trees has been practiced for many centuries. However, the use of PGRs to alter fruit tree physiology is a relatively new concept. Today, PGRs are vital to the apple industry. Among the commercial PGRs listed in the Farm Chemicals Handbook 2002 (Table 1), at least seven are used for producing apples. The following illustrates the research behind the co-evolution of PGR use and commercial apple production.

\section{FLOWER AND FRUIT REMOVAL}

Orchardists for centuries have recognized the usefulness of flower and fruit removal early in the season of the on-year to help counteract biennial bearing. Thinning was done by hand before 1940. Two divergent approaches to flower/fruit removal have been followed since then. On approach involves damaging the blossom with caustic sprays (blossom thinners). The other involves fruit removal with the use of hormone sprays (postbloom thinners).

BLOSSOM THINNERS. Auchter and Roberts (1934) were among the first to use of caustic sprays at bloom to regulate cropping by preventing fruit set. Copper sulfate, tar distillates and other caustic compounds reduced fruit set but caused unacceptable levels of leaf and fruit injury. One compound, sodium-4,6-dinitro-ortho-cresylate(DNOC), sold as Elgetol, emerged as an effective and relatively safe compound for reducing crop load to counteract biennial bearing (Batjer and Thompson, 1948). DNOC remained a blossom thinner of choice until its U.S. registration was withdrawn in 1990 by the Environmental Protection Agency because of a lack of support information necessary for re-registration. Replacement compounds including ammonium thiosulfate (ATS), endothalic acid (Endothall), pelargonic acid (Thinex), sulfcarbarmide-1-aminomethanamide hydrogem tetraoxosulfate (Wilthin), and hydrogen cyanamide (Dormex) have been evaluated as DNOC replacements (Bound and Jones, 1997; Byers, 1997; Fallahi, 1997; Williams, 1993). While none of these compounds have come close to achieving the commercial success of Elgetol, ATS has been among the most consistent in its thinning response. Other promising products considered organic thinners including lime-sulfur, fish oils, and various surfactants and vegetable oils are being evaluated. However, evaluation of these products has not proceeded to the point where their future value can be estimated.

Postbloom thinNers. Soon after the discovery and characterization of the endogenous hormone indoleacetic-acid (IAA), several synthetic auxins including naphthaleneacetic acid (NAA) and naphthaleneacetamide (NAD) were found to cause fruit abscission (Burkholder and McCown, 1941). Response to these thinners is influenced by cultivar, fruit size at time of application, and temperature following application (Williams and Edgerton, 1981). NAAremains an important thinning chemical especially where more aggressive thinning is appropriate.

The insecticide carbaryl is a mild thinner on apples (Batjer and Westwood, 1960). Carbaryl is rate-insensitive at concentrations over $750 \mathrm{mg} \cdot \mathrm{L}^{-1}$ (Southwick et al., 1964), thins over a wide range of fruit sizes (Knight and Spencer, 1987), breaks up fruit clusters (Looney and Knight, 1985) and rarely overthins. However, carbaryl has some limita-

Table 1. Commercial plant growth regulators. ${ }^{2}$

\begin{tabular}{|c|c|}
\hline Common name(s) & CAS chemical name \\
\hline $2,4-\mathrm{D}$ & (2,4-Dichlorophenoxy)acetic acid \\
\hline 2,4-DP & 2-(2,4-Dichlorophenoxy)propanoic acid \\
\hline 4-CPA & 4-Chlorophenoxyacetic acid \\
\hline Aviglycine; AVG & (2S,3E)-2-Amino-4-(2-aminoethoxy)-3-butenoic acid \\
\hline Ancymidol & $\alpha$-Cyclopropyl- $\alpha$-(4-methoxyphenyl)-5-pyrimidinemethanol \\
\hline Benzyladenine; 6-BA & $\mathrm{N}^{6}-($ Phenylmethyl)-1H-purin-6-amine \\
\hline \multicolumn{2}{|r|}{ 2-Naphthalenyloxyacetic acid } \\
\hline Butralin & 4-(1,1-Dimethylethyl)-N-(1-methylpropyl)-2,6-dinitrobenzenamine \\
\hline Carvone & 2-Methyl-5-(1-methylethenyl)-2-cyclohexene-1-one \\
\hline Chlormequat chloride & 2-Chloro-N,N,N-trimethylethanaminium chloride \\
\hline Chlorpropham; CIPC & (3-Chlorophenyl)carbamic acid 1-methylethyl ester \\
\hline Daminozide & Butanedioic acid mono(2,2-dimethylhydrazide) \\
\hline Decanol & 1-Decanol \\
\hline Diphenylamine; DPA & N-Phenylbenzeneamine \\
\hline Ethephon & (2-Chloroethyl)phosphonic acid \\
\hline Ethoxyquin & 6-Ethoxy-1,2-dihydro-2,2,4-trimethylquinoline \\
\hline Ethychlozate & Ethyl 5-chloro-3(1H)-indazolylacetate \\
\hline Flumetralin & 2-Chloro-N-[2,6-dinitro-4-(trifluoromethyl)pheny]-N-ethyl-6-fluorobenzenemethanamine \\
\hline Flurprimidol & $\alpha$-(1-Methylethyl)- $\alpha$-[4-(trifluoromethoxy)phenyl]-5-pyrimidinemethanol \\
\hline Forchlorfenuron; CPPU & 1-(2-Chloro-4-pyridyl)-3-phenylurea \\
\hline Gibberellin A3; Gibberellic acid; GA 3 & $(1 \alpha, 2 \beta, 4 \mathrm{a} \alpha, 4 \mathrm{~b} \beta, 10 \beta)-2,4 \mathrm{a}, 7-T r i h y d r o x y-1-m e t h y l-8$-methylenegibb-3-ene-1,10-dicarboxylic acid 1,4a-lactone \\
\hline Gibberellin A4/7; GA $/ \mathrm{GA}_{7}$ & $\begin{array}{l}\mathrm{GA}_{4}:(1 \alpha, 2 \beta, 4 \mathrm{a} \alpha, 4 \mathrm{~b} \beta, 10 \beta)-2,4 a-D i h y d r o x y-1-\text { methyl-8-methylenegibb-1,10-dicarboxylic acid 1,4a-lactone } \\
\mathrm{GA}_{7}:(1 \alpha, 2 \beta, 4 \mathrm{a} \alpha, 4 \mathrm{~b} \beta, 10 \beta)-2,4 \mathrm{a}, 7-T r i h y d r o x y-1-m e t h y 1-8-m e t h y l e n e g i b b-1,10 \text {-dicarboxylic acid 1,4a-lactone }\end{array}$ \\
\hline Hydrogen cyanamide & Cyanamide \\
\hline Indolebutyric acid; IBA & 1H-Indole-3-yl butyric acid \\
\hline Kinetin & N-(2-Furanylmethyl)-1H-purin-6-amine \\
\hline Maleic hydrazide & 1,2-Dihydro-3,6-pyridazinedione \\
\hline Mefluidide & N-[2,4-Dimethyl-5-[[[(trifluoromethyl) sulfonyl] amino]phenyl]acetamide \\
\hline Mepiquat chloride & 1,1-Dimethylpiperidinium chloride \\
\hline Naphthaleneacetic acid; NAA & 1-Naphthaleneacetic acid \\
\hline Naphthaleneacetic amide; NAD & 1-Naphthaleneacetamide \\
\hline Paclobutrazol & $(\alpha \mathrm{R}, \beta \mathrm{R})$-rel- $\beta$-[(4-Chlorophenyl)methyl]- $\alpha$-(1,1-dimethylethyl)-1H-1,2,4-triazole-1-ethanol \\
\hline Phthalamilic acid & N-Phenylphthalamic acid \\
\hline Prohexadione calcium & 3,5-Dioxo-4-(1-oxopropyl) cyclohexanecarboxylic acid \\
\hline Quinmerac & 7-Chloro-3-methyl-8-quinolinecarboxylic acid \\
\hline Thidiazuron; TDZ & N-Phenyl-N'-1,2,3-thiadiazol-5-ylurea \\
\hline Thiourea & Thiourea \\
\hline Trinexapac-ethyl & 4-(Cyclopropylhydroxymethylene)-3,5-dioxocyclohexanecarboxylic acid ethyl ester \\
\hline Uniconazole-P & (E)- $\beta$-[(4-Chlorophenyl)methylene $]-\alpha$-(1,1-dimethylethyl)-1H-1,2,4-triazole-1-ethanol \\
\hline
\end{tabular}

${ }^{2}$ Plant growth regulators with defined chemistries as listed in Farm Chemicals Handbook 2002 (Meister Publishing, 2002).

'Entry dates for compounds released before 1996 as listed in Global Herbicide Directory, 1998; NL = not listed. Entry dates for AVG, 6-BA, GA, and GA /GA, Ricardo Menendez, personal communication. 
tions. Since it is toxic to bees, applications must be delayed until bees are removed from the orchard. Further, carbaryl may be harmful to mite predators (Hislop and Prokopy, 1981) thus increasing the risk of mite infestations. Nevertheless, carbaryl is the most widely used chemical thinner in the U.S. (Greene, 2002a) although it is coming under increased regulatory scrutiny in Europe and the U.S. that may result in curtailed use or withdrawal of registration. Vydate, another carbamate registered for use on apples, has thinning activity similar to that reported for carbaryl (Byers et al., 1982).

Chemical thinning generally results in larger fruit size at harvest, due primarily to the reduction in competition among developing fruit. The cytokinin benzyladenine (6-BA) is the active thinning component in the most recently registered thinner. Like other thinners, 6-BAincreases fruit size by a reduction in competition, but unlike other thinners, it also increases fruit size by stimulating cell division (Wismer et al., 1995). 6-BA is generally considered a mild thinner when used by itself (Greene, 2002a).

During the first decades of commercial chemical thinning, emphasis was placed on conducting numerous trials to evaluate chemicals, concentrations, cultivars and local adaptations. The process was considered more art than science (Martin, 1979). Significant progress has been made in the past 25 years in gaining a better understanding of factors that influence thinner response and how to make chemical thinning more predictable (Forshey, 1986; Williams, 1979). Weather conditions following application play a dominant role in determining a thinner's ultimate effectiveness (Byers et al., 1991; Greene, 2002a; Schwallier, 1996). Critical to better understanding of thinner response are investigations on the mechanism of thinner action (Stopar, et al., 1997; Yuan and Greene, 2000).

\section{DEVELOPMENT AND MAINTENANCE OF TREE STRUCTURE}

The goal of orchardists is to develop a tree that efficiently intercepts a large portion of available light and yet has the structure that encourages the development of productive and fruitful wood. Twenty five years ago this goal was accomplished by planting trees on semi-dwarf rootstock at moderate densities, then developing a strong framework to support fruit. Plant bioregulators which contained 6-BA and $\mathrm{GA}_{4} / \mathrm{GA}_{7}$ were useful in developing the framework of these trees by stimulating lateral branching on young trees (Forshey, 1982; Miller and Eldridge, 1986). The gibberellins in these sprays inhibited flower bud formation for the following year, but were not considered a problem since tree structure was in the developmental stages and full production was not expected for several years. Recent economic analysis has shown that the most profitable orchards are those that fill their allotted space early. To achieve this, orchards are now planted at much higher densities on dwarfing rootstocks. Branching agents containing 6-BA + $\mathrm{GA}_{4} / \mathrm{GA}_{7}$ such as Promalin (Valent Biosciences Corp.) are now applied in the nursery at earlier tree development to stimulate branching (Cody et al., 1985). As a consequence, newly planted feathered trees already possess the scaffold structure that allows them to have significant production within 2 years after planting.

\section{VEGETATIVE GROWTH CONTROL}

Vegetative growth and cropping are delicately balanced. A balance

\begin{tabular}{|c|c|c|c|c|}
\hline Example brand & Company & Activity & Example use(s) & Entry date $^{b}$ \\
\hline Citrus Fix & Amvac Chemical Corp. & Auxin & Prevent citrus abscission & 1942 \\
\hline Dicopur DP & NuFarm & Auxin & Improve grape sizing & 1945 \\
\hline Fruitone & Amvac Chemical Corp. & Auxin & Improve grape sizing & 1945 \\
\hline ReTain & Valent Biosciences Corp. & Ethylene synthesis inhibitor & Delay pome fruit ripening and improve quality & 1997 \\
\hline A-Rest & SePRO Corp. & Gibberellin synthesis inhibitor & Inhibit ornamental growth & 1971 \\
\hline Accel & Valent Biosciences Corp. & Cytokinin & Promote apple fruit size & 1979 \\
\hline Blossom set & Cyclo International SA & Auxin & Improve blossom set & NL \\
\hline Tamex & CFPI-Nufarm & Growth inhibitor & Inhibit tobacco sucker growth & 1971 \\
\hline Talent & Luxan BV & Growth inhibitor & Inhibit potato sprouting & NL \\
\hline Cycocel Extra & BASF Corp. & Gibberellin synthesis inhibitor & Reduce cereal lodging & 1960 \\
\hline Endogerme $\mathrm{CP}$ & Chimac-Agriphar SA & Mitosis inhibitor & Inhibit potato sprouting & 1951 \\
\hline B-Nine & Uniroyal Chemical & Gibberellin synthesis inhibitor & Improve fruit development & 1962 \\
\hline Sucker Agent 504 & Drexel Chemical Co. & Undetermined & Inhibit tobacco sucker growth & NL \\
\hline No-Scald DPA 283 & Cerexagri Inc. & Antioxidant & Inhibit stored apple scald & NL \\
\hline Ethrel & Bayer & Ethylene releaser & $\begin{array}{l}\text { Enhance fruit color, promote sweet and sour cherry } \\
\text { fruit abscission, flower induction in pineapple }\end{array}$ & 1965 \\
\hline Deccoquin 305 & Cerexagri, Inc. & Antioxidant & Inhibit apple scald & NL \\
\hline Figaron & Fujisawa Pharmaceutical & Auxin & Thinning and ripening acceleration of citrus fruit & 1976 \\
\hline Prime+ & Syngenta & Growth inhibitor & Inhibit tobacco sucker growth & 1977 \\
\hline Cutless & Dow Agrosciences LLC & Gibberellin synthesis inhibitor & Inhibit turf growth & 1981 \\
\hline NL & SKW & Cytokinin & Improve grape and kiwi fruit size & 1983 \\
\hline ProGibb & Valent Biosciences Corp. & Gibberellin & $\begin{array}{l}\text { Improve size of grapes, improve quality of cherry } \\
\text { and citrus, alter flowering in sour cherry }\end{array}$ & 1962 \\
\hline Provide & Valent Biosciences Corp. & Gibberellin & Improve apple fruit finish & 1979 \\
\hline Dormex & SKW Trostberg AG & Undetermined & Synchronize grape bud break & 1982 \\
\hline Seradix & Bayer & Auxin & Promote rooting & 1935 \\
\hline X-Cyte & Stoller Enterprises, Inc. & Cytokinin & Biostimulant & NL \\
\hline Super Sprout Stop & Uniroyal Chemical & Growth inhibitor & Inhibit potato sprouting & 1949 \\
\hline Embark & Whitaker Distribution & Growth inhibitor & Inhibit turfgrass growth & 1974 \\
\hline Pix & BASF Corp. & Gibberellin synthesis inhibitor & Inhibit ornamental growth & 1972 \\
\hline Fruitone N & Amvac Chemical & Auxin & Fruit thinning in apples and citrus & 1939 \\
\hline Amid-Thin W & Amvac Chemical & Auxin & Fruit thinning in apples & NL \\
\hline Bonzi & Uniroyal Chemical & Gibberellin synthesis inhibitor & Inhibit ornamental growth & 1982 \\
\hline Nevirol & EMV Ltd. & Auxin transport inhibitor & Fruit thinning & 1982 \\
\hline Apogee & BASF Corp. & Gibberellin synthesis inhibitor & Inhibit apple vegetative growth & 1997 \\
\hline Bonus & BASF Corp. & Auxin & Improve rooting and fruit set & 1985 \\
\hline Dropp & Bayer & Cytokinin & Defoliation of cotton & 1976 \\
\hline Command & Ladda Co., Ltd. & Undetermined & Break dormancy & NL \\
\hline Primo MAXX & Syngenta Professional Products & Gibberellin synthesis inhibitor & Inhibit turf growth & 1988 \\
\hline Sumagic & Sumitomo Chemical Co., Ltd. & Gibberellin synthesis inhibitor & Inhibit ornamental growth & 1984 \\
\hline
\end{tabular}


within a tree that favors vegetative growth can reduce flowering, fruit set, fruit quality, pest control, and grower profit. Excessive vegetative growth can result from a weather event such as frost or inappropriate management decisions in thinning, fertilization, or pruning.

Trees propagated on vigorous and semi-dwarf rootstocks are generally slow to come into production. Growth retardation on these rapidly growing trees generally results in increased flower bud formation and fruit set. The growth retardants daminozide (Alar) and ethephon (Ethrel) came into regular use in the early 1970 s at a time when a number of apple tree were being planted on these more vigorous rootstocks. Used individually, both compounds inhibit vegetative growth and enhance flower bud formation. However, combination sprays were more effective and frequently the treatment of choice on young nonbearing trees (Greene, 1981). Daminozide did not cause fruit abscission and could be used safely to control growth on bearing trees. The registration for the use of daminozide on apples was withdrawn in 1989 due to concerns that it may be a carcinogen and that it caused an unacceptable level of risk for the development of cancer.

In addition to being an effective growth retardant, ethephon is also an effective thinner. Therefore, its use to control vegetative growth generally is restricted to application on young trees, trees that are biennial, or trees that have lost a crop due to frost. Some have expressed the concern that the use of ethephon on bearing trees may result in excessive flower bud formation, making thinning difficult, and thus initiating a biennial bearing cycle.

Paclobutrazol is a gibberellin biosynthesis inhibitor that was first reported by Quinlan (1980) to control growth on apple trees. Effective growth retardation may be achieved by application as a foliar spray, a soil drench around the trunk of a tree, by trunk injection, or in paint applied to the trunk (Miller, 1989). Spray application emerged as the favored method of application, and multiple sprays starting about 3 weeks after bloom were more effective than one application (Quinlan and Richardson, 1986). Since it is slowly metabolized within the tree, some growth retarding effects can persist within the tree for several years. Paclobutrazol is not registered for use on apples in the U.S., primarily due to concerns over ground water contamination, but is sold commercially in other countries.

Prohexadione-Ca (Apogee in the U.S., Regalis in Europe) is a growth retardant recently registered by BASF that acts by inhibiting gibberellin biosynthesis (Evans, etal., 1999). Since prohexadione-Ca degrades rapidly, it must be applied several times as soon as sufficient leaf tissue emerges, which is usually near petal fall. Prohexadione-Ca can increase fruit set, even when applied at moderate rates suggested on the label, and thus requires a more aggressive thinning program to achieve an appropriate level of fruit set (Greene, 1999). Most of its effects are secondary and generally attributed to increased light penetration due to a reduction in terminal growth. Prohexadione-Ca may control fire blight on shoots by inducing resistance in the tree (Yoder et al., 1999).

\section{FLOWERING AND FRUIT SET}

The present trend in apple production is to plant trees on precocious dwarfing rootstocks. For this reason there is little need to encourage additional flower buds on nonbearing trees. However, there is a need to enhance flowering on bearing trees, either to partially overcome biennial bearing or to increase flowering in marginal situations. Harley et al. (1958) reported that NAA increased flower bud formation in the absence of a thinning response, but little research has been done to fine tune this observation. Recently, production guides have recommended NAA to enhance flowering on bearing trees.

Ethephon promotes flowering but is also a strong thinner. However, multiple low doses starting at the end of June drop may be useful. Byers (1993) has shown that application of 100 to $200 \mathrm{mg} \cdot \mathrm{L}^{-1}$ of ethephon in 12 weekly or 6 biweekly sprays will enhance flower bud formation without thinning although it advanced fruit ripening.

The increased use of precocious rootstocks in apple orchards has lead to excessive fruit set. This increases limb breakage, diminishes tree growth, and does not allow trees to fill their allotted space. Sprays of 250 to 500 $\mathrm{mg} \cdot \mathrm{L}^{-1} \mathrm{GA}_{3}$ or $\mathrm{GA}_{4} / \mathrm{GA}_{7}$ can substantially reduce return bloom on young trees, thus improving tree growth and structure (Unrath and Whitworth, 1991). However, a similar use of gibberellins to regulate biennial bearing has not been as reliable on bearing trees (Greene, 2000).

Gibberellins can increase fruit set, but their general use for this purpose has not become widespread because of unpredictable response, reduced fruit size, and inhibition of flower bud formation. Prohexadione-Ca increases fruit set especially in cooler growing regions (Greene, 1999). Often increased fruit set on bearing trees is considered undesirable since small fruit size and reduced fruit size are the usual consequences. However, in situations where bloom is light and pollinating conditions marginal sprays of prohexadione-Ca may well be beneficial to increasing fruit set and help control vegetative growth on lightly cropping trees. Aminoethoxyvinylglycine (AVG) can increase fruit set when applied as a petal fall spray (Greene 1980; Williams, 1980).

\section{PREHARVEST DROP}

Preharvest drop is a serious problem. Some cultivars such as 'McIntosh' are particularly prone to preharvest drop. In areas where one or two cultivars dominate, the problem is further complicated since growers are faced with the challenge of harvesting a large portion of their crop before fruit condition declines and fruit are lost due to drop.

Auxins can inhibit preharvest drop. Although many auxins were tested and some were used, the only auxin to survive regulatory scrutiny and the reregistration process was NAA. NAA does not enjoy widespread use today for several reasons. First, two applications may be necessary since the effect lasts only 7 to 10 days. If two applications are used, an additional 7 days of drop control can be expected. Second, ripening is often advanced and reduces storage life. Marini et al.,(1993) reported that repeat application well in advance of the start of drop may be an effective way to control preharvest drop on 'Delicious' without subjecting the trees to unwanted side effects. Unrath (1996) suggested 4 weekly applications of $5 \mathrm{mg} \cdot \mathrm{L}^{-1}$ NAA starting 4 weeks before anticipated harvest.

Daminozide was the preharvest drop compound of choice for most cultivars for over 20 years starting in the late 1960s. Not only did it retard drop, but it also increased flesh firmness and red color (Edgerton and Hoffman, 1965). Withdrawal of registration of daminozide in 1989 left growers with NAA as the only preharvest drop control option.

Bangerth (1978) first reported that multiple applications of aminoethoxyvinylglycine (AVG), an ethylene biosynthesis inhibitor, retarded preharvest drop of apples. ReTain, an AVG product developed and formulated by Abbott Laboratories (now Valent BioSciences Corp.) was granted full registration by the U.S. Environmental Protection Agency in 1997. AVG has become the dominant PGR used to retard preharvest drop on apples in the U.S.

\section{IMPROVING FRUIT APPEARANCE AND SHAPE}

'Delicious' dominates the apple in the market today. The public prefers blocky fruit with prominent calyx lobes. Sprays containing equal amounts of 6-BAand GA $/ \mathrm{GA}_{7}$ at bloom have been used since the 1970 s to improve fruit shape. The cytokinin (N-(2-chloro-4-pyridyl)-N-phenylurea (CPPU) applied at bloom may be even more effective at elongating 'Delicious' (Curry and Greene, 1993), but it has not been registered on apples.

Regions where the weather is typically rainy, moist, and humid during the post bloom period have fruit that appear russetted. If severe, the grade of fruit can be reduce. Two to four postbloom applications of products containing $\mathrm{GA}_{4} / \mathrm{GA}_{7}$ will reduce russeting.

\section{INFLUENCING FRUIT MATURITY AND QUALITY}

The goal of orchardists is to harvest fruit at optimum maturity for best eating quality or at a stage of maturity that will assure near-optimum eating quality out of storage. Because a large number of fruit must be harvested in a short period of time, strategies to advance or delay ripening are appropriate.

Many studies in the 1970s developed protocols to advance ripening and increase red color of apples using ethphon. In general 62.5 to $125 \mathrm{~mL} / 100 \mathrm{~L}$ was applied 1 to 3 weeks before normal harvest. These sprays included a drop control compound. Fruit were then harvested 7 to 10 days after application and were intended for short term storage. This general approach to advancing fruit ripening of apples for early sale is still used. 
Daminozide was used to delay apple ripening (Edgerton and Hoffman, 1965). This not only extended the harvest season but it delayed the loss of fruit firmness and some instances reduced the incidence of physiological disorders such as watercore (Lord et al., 1967). AVG has now replaced daminozide and is the only product on the market that can delay ripening on the tree. AVG can reduce watercore, one of the major causes of internal breakdown in storage (Greene, 2002b). Fruit receiving AVG are generally firmer at harvest, but the extent of this firmness increase appears to be quite variable.

Recently, the ethylene action blocker, 1-methylcyclopropene (1-MCP) was introduced as SmartFresh by AgroFresh for postharvest application to maintain apple quality through long-term storage (Blakenship and Unrath, 1998).

\section{FUTURE COMMERCIAL PGR OPPORTUNITIES}

Previous authors have speculated on the future of commercial PGRs (Carlson and Crovetti, 1990; Cibulsky and Crovetti, 1981; Crovetti and Shafer, 1988; Rademacher and Bucci 2002; Schott and Walter, 1991; Thomas, 1982). In general, to bring new commercial PGRs to market successfully, the products consistently must fill an economically important need of the customer and they must be sufficiently inexpensive to register and produce. Moreover, the targeted agricultural industries must be viable, the partnerships between companies and academia must be strong, and the companies must be willing to take the risk to develop a concept into a product.

\section{CURRENT CHALLENGES FOR NEW PGR DEVELOPMENT}

Market forces are delaying the development of new PGRs. The development of agricultural chemicals is closely tied to the health of the agricultural industry. As agricultural production has become more global, the margins of growers in mature markets have eroded. Also affecting interest in the developing new active ingredients include the increased cost of discovering, developing, and registering new compounds, increased generic competition, rise of transgenic crops, and domination of glyphosate in the herbicide market. These challenges have resulted in a reduced willingness of some companies to invest in the development of new PGRs.

\section{OPPORTUNITIES FOR NEAR TERM GROWTH IN PGRS}

In the near term, currently known PGRs make up the greatest number of product opportunities in the marketplace. First, among the currently commercialized products, continued label expansion of newer PGRs, such as AVG, will broaden their use on new crops. Second, PGR development opportunities exist in known, but not commercialized PGRs such as S-ABA, jasmonates, and brassinosteroids. Reduced production costs may make these PGRs commercially viable. Third, new markets such as organic farming or high quality fruit and vegetables may provide significant opportunities for new PGR uses. Fourth, plant systemic acquired resistance (SAR) inducers such as Actigard may become effective tools disease control programs.

\section{OPPORTUNITIES FOR LONG-TERM GROWTH IN PGRS}

In the longer term, new uses for PGRs will be discovered in at least three ways: 1) systematic screening, 2) dissection of biological phenomena, and 3) chance discovery. While all of these methods have existed in the past, there have been changes in the way in which these are performed. New methods, such as the use of genomics to identify targets and bioinformatics to identify patterns in high throughput screening data, provide new tools for discovery.

Systematic screening will continue to be an important means of identifying new agricultural chemicals. Such screening of large numbers of synthesized chemicals for use against weeds, pathogens, and other pest targets has led to many new products. However, these screenings require large inputs of labor, time, and space. To reduce the inputs, acceleration of the primary screens is necessary for high-throughput screening. One technique for accelerating the assay is to use molecular targets, developed through genomics, as opposed to phenotypic targets.
Molecular targets allow for screening in cell culture in a single 96-well plate that, in the past, would have required the production of hundreds of greenhouse-grown plants. Moreover, the new primary screens might only require a few milligrams of compound, as opposed to the hundreds of milligrams that a traditional screen might have used.

The dissection of biological phenomena has continued to reveal roles for PGRs. Arabidopsis and molecular tools have allowed for new approaches to look at interesting problems. For example, in the previous decade, researchers demonstrated a development role for both brassinosteroids and cytokinins in de-etiolation of Arabidopsis (Chory et al., 1994; Fujioka et al., 1997). This work may lead to a greater understanding of the value of brassinosteroids in commercial agriculture. Other researchers will undoubtably also demonstrate roles for endogenous PGRs as more complex phenomena are examined molecularly.

Chance discovery will also continue to play a role in PGR development. There continue to be opportunities for careful observations to make an impact on PGR development. For example, ethephon may have a significant impact on the activity of photosystem I inhibiting herbicides (Silverman and Petracek, personal communication). While the idea of modulating herbicide activity with PGRs is not new (Sterrett et al., 1983), this particular finding confirms that there may be more opportunities for PGR discovery than we might expect.

\section{Literature Cited}

Auchter, E.C. and R.H. Roberts. 1934. Experiments in spraying apples for the prevention of fruit set. Proc. Amer Soc. Hort. Sci. 30:22-24.

Bandurski, R.S. and H.M. Nonhebel. 1984. Auxins, p. 2-20. In: M.B. Wilkins (ed.). Advance plant physiology. Pitman Publishing Ltd., London, U.K.

Bangerth,F. 1978. The effect of a substituted amino acid on ethylene biosynthesis, respiration, ripening, and preharvest drop of apple fruit. J. Amer. Soc. Hort. Sci. 103:401-404.

Batjer,L.P. and A.H. Thompson. 1948. Three years' results with chemical thinning of apples in the northwest. Proc. Amer. Soc. Hort. Sci. 52:164-172.

Batjer, L.P. and M.N. Westwood. 1960. 1-Naphthyl N-methylcarbamate, a new chemical for thinning apples. Proc. Amer. Soc. Hort. Sci. 75:1-4.

Beyer, Jr., E., P.W. Morgan, and S.-F. Yang. 1984. Ethylene, p. 111-126. In: M.B. Wilkins (ed.). Advanced plant physiology. Pitman Publ., London, U.K.

Blankenship, S.M. and C.R. Unrath. 1998. Ethylene inhibitor, 1-methylcyclopropene, delays apple softening. HortScience 33:469 (abstr.).

Bonner, D.M. 1940. Leaf growth factors. PhD diss. Calif. Inst. Technol., Pasadena.

Bound, S.S. and K.M. Jones. 1997. Investigating the efficacy of endothall as a chemical thinner on red 'Delicious' apple. J. Hort. Sci. 72:171-177.

Brian, P. and H. Hemming, 1955. The effect of gibberellic acid on shoot growth of pea seedlings. Physiol. Plant. 8: 669-681.

Bukovac, M. 1987. Plant hormone research-A continuing challenge. William Henry Hatch Centennial Year Lecture, USDA, Wash., D.C.

Burkholder, C.L. and M. McCown. 1941. Effect of scoring and of a naphthyl acetic acid and amide spray upon fruit set and of the spray upon preharvest drop. Proc Amer. Soc. Hort Sci. 38:117-120.

Byers, R.E. 1993. Controlling growth of bearing apple trees with ethephon. HortScience 28:1103-1105.

Byers, R.E. 1997. Effects of bloom-thinning chemicals on apple fruit set. J. Tree Fruit Prod. 2:13-31.

Byers, R.E., D.H. Carbaugh, C.N. Priestly, and T.K. Wolf. 1991. The influence of low light on apple fruit abscission. J. Hort. Sci.66:7-17.

Byers, R.E., C.G. Lyons, and R.L. Horsburgh. 1982. Comparison of Sevin and Vydate for thinning apples. HortScience 17:777-778.

Carlson, R.D. and A.J. Crovetti. 1990. Commercial uses of gibberellins and cytokinins and new areas of applied research, p. 604-610. In R.P. Pharis and S.B. Rood (eds.). Plant growth substances 1988. Springer-Verlag, Berlin, Germany.

Chory, J., D. Reinecke, S. Sim, T. Washburn, and M. Brenner. 1994. A role for cytokinins in de-etiolation in Arabidopsis. Plant Physiol. 104:339-347.

Cibulsky, R. J. and A. J. Crovetti. 1981, Growth regulator-Outlook for the future from the industrial viewpoint. Acta Hort. 120:31-36.

Cody, C., F.E. Larsen, and R Fritts, Jr. 1985. Stimulation of later branch development in tree fruit nursery stock with $\mathrm{GA}_{4+7}+\mathrm{BA}$. HortScience 20: $758-759$.

Crovetti, A.J. and W.E. Shafer. 1988, Considerations in the commercial development of plant growth regulators. 6th Intl. Symp. Growth Regulators in Fruit Production. p. 465-476.

Curry, E.A. and D.W. Greene. 1993. CPPU influences fruit quality, fruit set, return bloom, and preharvest drop of apples. HortScience 28:115-119.

Davies, P. 1995. Plant hormones: Physiology, biochemistry and molecular biol- 
ogy. 2nd ed. Kluwer Academic Publishers, Boston, Mass.

Edgerton, L.J. and M.B. Hoffman. 1965. Some physiological responses of apples to $\mathrm{N}$-dimethyl amino succinamic acid and other growth regulators. Proc. Amer. Soc. Hor Sci. 57:120-124.

Evans, R.J., R.R. Evans, C.L. Regusci, and W. Rademacher. 1999. Mode of action, metabolism, and uptake of BAS $125 \mathrm{~W}$, prohexadione-calcium. HortScience 34:1200-1201.

Fallahi, E. 1997. Application of endothalic acid, pelargonic acid, and hydrogen cyanamide for blossom thinning in apple and peach. HortTechnology 7 : 395-399.

Forshey, C.G. 1986. Chemical thinning of apples. N.Y. Food Life Sci. Bul. 116.

Forshey, C.G. 1982. Branching response of young apple trees to applications of 6-benzylamino purine and gibberellins $\mathrm{A}_{4+7}$. J. Amer. Soc. Hort. Sci. 107:538-541.

Fujioka, S., J. Li, Y.-H. Choi, H. Seto, S. Takatsuto, T. Noguchi, T. Watanabe, H. Kuriyama, T. Yokota, J. Chory, and A. Sakurai. 1997. The Arabidopsis deetiolated mutant is blocked early in brassinosteroid biosynthesis. Plant Cell 9: 1951-1962.

Global herbicide directory. 2nd ed. 1998. Global herbicide directory. Orpington, U.K.

Greene, D.W. 1980. Effect of silver nitrate, aminoethhoxyvinylglycine and gibberellins $\mathrm{A}_{4+7}$ plus 6-benzyl-aminopyrine on fruit set and development of 'Delicious' apples. J. Amer. Soc. Hort Sci. 105:717-720.

Greene, D.W. 1981. Growth regulator application and cultural techniques to promote early fruiting of apples, p. 117-14. In: R.B. Tukey and M.W. Williams (eds.).Proc. 181 Pacific Northwest Tree Fruit Shortcourse, Wash. Sta. Coop. Ext. Ser., Pullman.

Greene, D.W. 1999. Tree growth management and fruit quality of apple trees treated with prohexadione-calcium (BAS 125). HortScience 34 1209-1212.

Greene, D.W. 2000. Reducing floral initiation and return bloom in pome fruit trees - Application and implications. HortTechnology 10:740-743.

Greene, D.W. 2002a. Chemicals, timing, and environmental factors involved in thinner efficacy on apple. HortScience 37(3):477-481

Greene,D.W. 2002b. Preharvest drop control and maturity of 'Delicious' apples as affected by aminoethoxyvinylglycine (AVG). J. Tree Fruit Prod. 3:1-10.

Harley, C.P.,H.H. Moon, and L.O. Regeimbal. 1958. Evidence that posts-bloom apple- thinning sprays of naphthaleneacetic acid increase blossom-bud formation. Proc. Amer. Soc. Hort. Sci. 72:52-56.

Hislop, R.G. and R.J. Prokopy. 1981. Integrated management of phytophagous mites in Massachusetts (USA) apple orchards: II. Influence of pesticides on the predator Amblyseius fallacis (Acarina: Physeiidae) under laboratory and field conditions. Protection Ecol. 3:157-172.

Jacobs, W. 1979. Plant hormones and plant development. Cambridge Univ. Press, New York.

Knight, J.N. and J.E. Spencer. 1987. Timing of application of carbaryl used as an apple fruitlet thinner. J. Hort. Sci. 62:11-16.

Letham, D. 1963. Zeatin, a factor inducing cell division from Zea mays. Life Sci. 2:569-573.

Looney, N.E. and J.E. Knight. 1985. Effects of initial set and carbaryl treatment on final fruit set on 'Greensleeves' apple. HortScience 20:400-401.

Lord, W.J., F.W. Southwick, and R.A. Damon. 1967. The influence of N-dimethyl amino succinamic acid on flesh firmness and some pre- and post-harvest physiological disorders of 'Delicious' apples. Proc. Amer. Soc. Hort. Sci. 91:829-832.

Marini, R.P., R.E. Byers, and D.L. Sowers. 1993. Repeat applications of NAA control preharvest drop of 'Delicious' apples. J. Hort. Sci. 68:247-253.

Martin, G.C. 1979. Growth regulators in pomology: The end of the beginning. HortScience 14:326-328.

Meister Publishing, 2002. Farm chemicals handbook. vol. 88. Meister Publ., Willoughby, Ohio.

Milborrow, B. 1984. Inhibitors, p. 76-110. In: M.B. Wilkins (ed.). Advanced plant physiology. Pitman Publishing, London, U.K.

Miller, C., F. Skoog, F. Okumura, M. Von Saltza, and F. Strong. 1955. Kinetin, a cell division factor from deoxyribonucelic acid. J. Amer. Chem. Soc. 77: 1392.

Miller, S.S. 1989. Plant bioregulators in apple and pear culture. Hort Rev. 10: 309-402.

Miller, S.S. and B.J. Eldridge. 1986. Use of 6-benzylamino purine and Promalin for improved canopy development in selected apple cultivars. Scientia Hort. 28:255-368.

Phinney, B.O. 1983. The history of gibberellins, p. 19-52. In: A. Crozier (ed.). The biochemistry and physiology of gibberellins. vol. 1. Praeger Publ., New York

Quinlan, J.D. 1980. Recent developments in the chemical control of tree growth. Act Hort. 114:144-151.

Quinlan,J.D. and P.J. Richardson. 1986. Uptake and translocation of paclobutrazol and implications for orchard use. Acta Hort. 179:443-452.

Rademacher, W. and T. Bucci. 2002. New plant growth regulators: High risk investment? HortTechnology 12:64-67.

Reid, J.B. and S.H. Howell. 1995. Hormone mutants and plant development, p. 448-485. In: P.J. Davies (ed.). Plant hormones: Physiology, biochemistry and molecular biology. 2nd ed. Kluwer Academic Publ., Boston.

Salisbury, F. and C. Ross. 1992. Plant physiology. Wadsworth Publ., Belmont, Calif.

Schott, P.E. and H. Walter. 1991. Bioregulators: Present and future fields of application, p. 247-321. In: H.W. Gausman (ed.). Plant biochemical regulators. Marcel Dekker, New York.

Schwailler, P.G. 1996. Apple thinning guide. Great Lakes Publ. Co., Sparta, Mich.

Southwick, F.W., W.D. Weeks, and G.W. Olanyk. 1964. The effect of naphthaleneacetic acid type materials and N-methylcarbamate (Sevin) on fruiting, flowering and keeping quality of apples. Proc. Amer. Soc. Hort. Sci. 84: 14024.

Sterrett, J. and R. Hodgson. 1983. Enhanced response of bean (Phaseolus vulgaris) and Canada thistle (Cirsium arvense) to bentazon or glyphosate by gibberellin. Weed Sci. 31:396-401.

Stopar, M., B.L. Black, and M.J. Bukovac. 1997. The effect of NAA and BA on carbon dioxide assimilation by shoot leaves of spur-type 'Delicious' and 'Empire' Apples. J. Amer. Soc. Hort. Sci. 122:837-840.

Thomas, T.H. 1982, Plant growth regulator potential and practice. Lavenham Press Ltd., Lavenham, Suffolk, U.K.

Unrath, C.R. 1996. Drop control in apples-NAA to AVG, p. 1-4. In: W. Kleiner and G. Greene (eds.). Using plant growth regulators in the orchard for profit. 1996 PSU Fruit School, Pa. State Univ., University Park.

Unrath, C.R. 1999. Prohexadione-Ca: A promising chemical for controlling vegetative growth of apples. HortScience 34:1197-1200.

Unrath, C.R. and J. Whitworth. 1991. Suppression of apple bloom with gibberellin sprays. J. Hort. Sci. 66:155-157.

Williams, M.W. 1979. Chemical thinning of apples. Hort. Rev. 1:270-300.

Williams. M.W. 1980. Retention of fruit firmness and increase in vegetative growth and fruit set of apples with aminoethoxyvinylglycine. HortScience 15:76-77.

Williams, M.W. and L.J. Edgerton. 1981. Fruit thinning of apples and pears with chemicals. USDA Agr. Bul. 289.

Williams, M.W. 1993. Sulfcarbamide, a blossom-thinning agent for apples. HortTechnology 3:322-324.

Wilkins, M. 1984. Advanced plant physiology. Pitman Publishing Ltd., London, U.K.

Wismer, P.T., J.T.A. Proctor, and D.C. Elfving. 1995. Benzyladenine affects cell division and cell size during apple fruit thinning. J. Amer. Soc. Hort. Sci. 120:802-807.

Yoder, K.S., S.S. Miller, and R.E. Byers. 1999. Suppression of fireblight in apple shoots by prohexadione-calcium following experimental and natural inoculation. HortScience 43:1202-1204.

Yuan, R. and D.W. Greene. 2000. Benzyladenine as a chemical thinner for 'McIntosh' apples. I. Fruit thinning effects and associated relationships with photosynthesis, assimilate translocation, and nonstructural carbohydrates. J. Amer. Soc. Hort. Sci. 125:169-176. 